\title{
The Effects of Steroid Therapy on Bone and Eyes in Children with Nephrotic Syndrome
}

\author{
Serap Genç Yüzüak, ${ }^{1}$ Bülent Ataş²
}

'Department of Pediatrics, Kartal Dr. Lütfi Kırdar Training and Research Hospital, İstanbul, Turkey

${ }^{2}$ Department of Pediatrics, Division of Nephrology, Necmettin Erbakan University, Meram Faculty of Medicine, Konya, Turkey

Submitted: 10.12.2016 Accepted: 25.08.2017

Correspondence: Bülent Ataş, Necmettin Erbakan Üniversitesi, Meram Tıp Fakültsi, Çocuk Nefroloji Anabilim Dalı Konya, Turkey

E-mail: bulentatas@hotmail.com

口isto

Keywords: Bone mineral density; corticosteroid; nephrotic syndrome; ocular complications.

\begin{abstract}
Objective: The aim of this study was to evaluate complications of long-term steroid usage on the eyes and bone metabolism, which can be detected at early stage, and to encourage the necessary precautions.
\end{abstract}

Methods: This retrospective study was performed with data of patients who took steroid therapy for nephrotic syndrome and were followed up between June 2006-May 20II at Necmettin Erbakan University.

Results: Fifty-six patients were included in this study. The mean age of the patients was $4.2 \pm 2.3$ years. The patients were examined in 3 groups according to steroid therapy. Group I was defined as patients who had not received steroids in the past year and who were in the remission stage, Group 2 comprised patients who had received steroids in the last year and who were in the remission stage, and Group 3 was made up of patients who were in the active nephrotic period and had received steroids. In terms of biochemical parameters (serum urea, creatinine, calcium, phosphorus, magnesium, alkaline phosphatase, parathyroid hormone, osteocalcin, vitamin $D$, triglycerides), there was no statistically significant difference between the 3 groups. Group 3 had a higher ratio of calcium/creatinine and protein/ creatinine in spot urine than Groups I and 2. Of 56 patients, 40 patients had eye examinations. There was no statistically significant difference determined in terms of side effects of steroid treatment.

Conclusion: Pediatricians should be very careful while following up the children who use steroids at a young age due to the possibility of cataract development and side effects on bone metabolism.

\section{INTRODUCTION}

Nephrotic syndrome (NS) is a disease characterized by significant proteinuria, hypoproteinemia, edema, and hyperlipidemia as a result of increased glomerular permeability. ${ }^{[l]}$ Twothirds of childhood NS cases are observed before the age of 5 , and $80 \%$ to $85 \%$ of them lead to minimal lesion disease (MLD). ${ }^{[2,3]}$ NS diagnosis includes urinary protein excretion of more than $40 \mathrm{mg} / \mathrm{m}^{2} / \mathrm{h}$ and hypoalbuminemia (serum albumin $<2.5 \mathrm{gr} / \mathrm{dL}$ ). ${ }^{[4]}$ Approximately $90 \%$ of patients respond to steroids and remission is observed in the first 4 weeks. ${ }^{[5,6]}$
The glucocorticoid drugs used for NS have important side effects on bone metabolism. One of these side effects is the development of osteoporosis. ${ }^{[7]}$ Harvey Cushing first described the effects of steroids on bone tissue in 1932. There are various factors in the pathogenesis. ${ }^{[8]}$ Systemic glucocorticoids can lead to bone loss directly or indirectly, suppress the growth hormone secretion, and inhibit the synthesis of insulin-like growth factor I. As a result of growth factor inhibition, there is a decrease in the number and activity of osteoblasts. Osteoclasts are activated, and calcium absorption from the intestinal mucosal cells 
decreases. Renal excretion of calcium and phosphorus increases. Thus, hypocalcemia develops and can cause secondary hyperparathyroidism. The rate of bone remodeling increases, but there is insufficient bone formation as osteoblasts are suppressed. Finally, osteoporosis and bone resorption occur. These effects are dependent on dose and the length of use; the impact increases in higher doses and long-term treatment. ${ }^{[9]}$

Long-term use of glucocorticoids is a significant risk factor for the development of posterior subcapsular cataract. Glucocorticoids can also increase intraocular pressure. This type of glaucoma generally happens in patients who use glucocorticoid eye drops. Exophthalmos and swelling of the eyelids and eye muscles is also a rarely observed side effect of glucocorticoids. ${ }^{[10]}$ Another possible side effect of systemic, local, or topical glucocorticoid use is central serous chorioretinitis. ${ }^{[1]}$

In the present study, the effects of steroid treatment on serum concentrations of calcium, phosphorus, magnesium, alkaline phosphatase, parathyroid hormone, vitamin D, osteocalcin, bone density, and the eyes of children with steroid-sensitive NS were examined. The aim was to detect any complications in the eyes or bones due to long-term steroid use at an early stage and to ensure the necessary precautions are taken.

\section{MATERIAL AND METHODS}

This study was performed with patients with NS due to MLD who were followed up between 2006 and 20II at Necmettin Erbakan University, Meram Medical Faculty, Department of Children's Health and Diseases, Pediatric Nephrology Unit. The Meram Medical Faculty ethics committee of Selçuk University granted approval for the study on March 28, 201 I (decision number I I0). Hospital records of 56 patients with NS were analyzed retrospectively. The patients were divided into 3 groups.

Group I: Patients who did not receive steroids in the last year and who were in the remission stage.

Group 2: Patients who had received steroids in the last year and who were in the remission stage.

Group 3: Patients who were in active nephrotic period (with urine protein/creatinine value $>2$ ) and had received steroids.

Data of creatinine, albumin, total calcium, phosphorous, magnesium, alkaline phosphatase, parathyroid hormone, 25-hydroxyvitamin D3, osteocalcin, cholesterol, triglyceride, and urine protein, calcium, and creatinine levels measured at the same time were collected from patients files and recorded, as well as bone mineral density and eye examination findings.

Urea, creatinine, albumin, phosphorus, magnesium, al- kaline phosphatase, total cholesterol, triglyceride, spot urine creatinine, and spot urine microprotein levels were measured using spectrophotometric calorimetric testing. Calcium, and spot urine calcium levels were measured using ion-selective electrodes, parathyroid hormone was measured using chemiluminescence, osteocalcin level was measured using an enzyme-linked immunosorbent assay and 25-hydroxyvitamin vitamin D3 level was measured using high-performance liquid chromatography. Patient bone density was measured using the linear absorption dual energy X-ray absorptiometry (DXA) technique. Z-score of less than -2 SD was considered osteoporosis and Z-score between -I SD and -2 SD was classified as osteopenia. ${ }^{[12]}$

Disease duration of the patients was determined, as well as total prednisolone dose $(\mathrm{mg})$ given from disease onset until bone parameters were measured and eye examination was performed.

\section{Statistical analysis}

Statistical evaluation was performed using SPSS for Windows, Version 16.0. (SPSS Inc., Chicago, IL, USA). Findings were expressed as mean $\pm S D$. Normality analysis was performed to evaluate distribution. The 3 patient groups were compared in terms of biochemical parameters using a one-way analysis of variance (ANOVA). A post hoc test was performed for variables that were found to be significant. The total steroid dose ( $\mathrm{mg}$ and $\mathrm{mg} / \mathrm{kg}$ ) was also compared between groups using an ANOVA test. Bone density was compared in terms of osteopenia and osteoporosis using the chi-square test. In all analyses, 5\% significance level was used.

\section{RESULTS}

A total of 56 idiopathic, steroid-sensitive NS patients were included in the study. Of those, 35 (62.5\%) were male and 21 (37.5\%) were female. The mean age of the patients was $4.2 \pm 2.3$ years. The age of patients at the time of diagnosis, disease duration, number of relapses, and DXA Z-scores are presented in Table I.

The patients were evaluated in 3 groups. There was a total of 20 patients in Group I (I 3 males, 65\%; 7 females, $35 \%$ ), there were 33 patients in Group 2 (20 males, 60\%; 13 females $40 \%$ ), and there were 3 patients in Group 3 (2 males, $67 \%$; I female $33 \%$ ).

Comparison of the 3 groups in terms of biochemical parameters (serum urea, creatinine, calcium, phosphorus, magnesium, alkaline phosphatase, parathyroid hormone, osteocalcin, vitamin $\mathrm{D}$, triglycerides) revealed no statistically significant difference $(p>0.05)$. However, there was a significant difference in the rate of calcium/creatinine and protein/creatinine in spot urine $(p<0.05)$. Similarly, total serum cholesterol levels were also significantly dif- 
Table I. The age of patients at the time of diagnosis, disease duration, number of relapses, and dual energy X-ray absorptiometry Z-score

\begin{tabular}{lccc}
\hline Parameters & Mean \pm SD & Max. & Min. \\
\hline Age at diagnosis (years) & $4.22 \pm 2.37$ & 11.74 & 0.99 \\
Disease duration (years) & $5.24 \pm 4.02$ & 14.03 & 0.47 \\
Number of relapses & $2.23 \pm 2.21$ & 9 & 0 \\
DXA Z-score & $-0.54 \pm 0.89$ & 1.8 & -2.6 \\
\hline
\end{tabular}

SD: Standard deviation; Max.: Maximum; Min.: Minimum; DXA: Dual energy $\mathrm{X}$-ray absorptiometry.

ferent between groups $(p<0.05)$. There was a statistically significant difference between Group 3 and Group I, and between Group 3 and Group 2 ( $p=0.001$, $p=0.022$, respectively) in the urine protein/creatinine rate. Similarly, there was a statistically significant difference between Group 3 and Group I, and between Group 3 and Group 2 ( $p=0.00$ I, $p=0.0$ I, respectively) in the urine calcium/creatinine rate. Comparison of total serum cholesterol level also revealed a statistically significant difference between Group 3 and Group I, and between Group 3 and Group 2 (Group I and Group 2: $p=0.999$; Group I and Group 3: $p=0.007$; Group 2 and Group 3: $p=0.005$ ). The biochemical parameters of the patients can be seen in Table 2 .

When the total steroid doses of the 3 groups were compared, no statistically significant difference was found $(p=0.290)$. The total steroid doses of patient groups are provided in Table 3.

The bone density of 43 patients was measured and the results can be seen in Table 4. The bone density of the 3 groups was compared in terms of osteopenia and osteoporosis with the chi-square test, and no statistically significant difference was found $(p=0.306)$.

The bone density of the 3 groups was compared in terms of gender using the chi-square test, and no statistically significant difference was found $(p>0.05)$. The distribution of bone density measurements according to gender can be seen in Table 5.

Eye examinations were performed on 40 patients from the

Table 2. Biochemical characteristics of the patients

\begin{tabular}{|c|c|c|c|c|c|c|c|}
\hline \multirow[b]{2}{*}{ Bone parameters } & \multicolumn{2}{|c|}{ Group I } & \multicolumn{2}{|c|}{ Group 2} & \multicolumn{2}{|c|}{ Group 3} & \multirow[t]{2}{*}{$\mathbf{p}$} \\
\hline & Mean \pm SD & Min.-Max. & Mean $\pm S D$ & Min.-Max. & Mean \pm SD & Min.-Max. & \\
\hline Urea (mg/dL) & $17.30 \pm 3.88$ & $10-26$ & $20.75 \pm 6.54$ & $10-46$ & $23.33 \pm 3.78$ & $19-26$ & $=0.058$ \\
\hline Creatine (mg/dL) & $0.47 \pm 0.12$ & $0.30-0.72$ & $0.36 \pm 0.11$ & $0.12-0.60$ & $0.26 \pm 0.04$ & $0.21-0.30$ & $=0.002$ \\
\hline Calcium (mg/dL) & $9.60 \pm 0.63$ & $8.50-10.50$ & $9.70 \pm 0.48$ & $8.50-10.30$ & $8.63 \pm 0.64$ & $7.90-9.10$ & $=0.008$ \\
\hline Phosphorus (mg/dL) & $4.69 \pm 0.82$ & $3.30-6.70$ & $4.80 \pm 0.88$ & $2.90-6.20$ & $4.03 \pm 0.30$ & $3.70-4.30$ & $=0.333$ \\
\hline Magnesium (mg/dL) & $2.18 \pm 0.23$ & $1.79-2.70$ & $2.15 \pm 0.20$ & $1.80-2.59$ & $2.18 \pm 0.18$ & $2-2.36$ & $=0.890$ \\
\hline Alkaline phosphatase (U/L) & $195.38 \pm 88.75$ & $47-372$ & $172.58 \pm 43.36$ & $79-265$ & $120 \pm 19.67$ & $|02-| 4 \mid$ & $=0.133$ \\
\hline Parathyroid hormone (pg/mL) & $79.01 \pm 91.84$ & $19.5-446$ & $48.12 \pm 39.43$ & $15.30-236$ & $49.60 \pm 21.27$ & $30.80-72.70$ & $=0.230$ \\
\hline Osteocalcin (ng/mL) & $25.24 \pm 19.47$ & $2.50-66.08$ & $20.32 \pm 13.32$ & $0.7-46.40$ & $6.31 \pm 6.13$ & $2.70-13.40$ & $=0.142$ \\
\hline Vitamin $D(\mathrm{ng} / \mathrm{mL})$ & $22.05 \pm 13.16$ & $4.80-47.10$ & $22.24 \pm 12.88$ & $4.40-70.20$ & $30.33 \pm 15.04$ & $|3.30-4| .80$ & $=0.58 \mathrm{I}$ \\
\hline Cholesterol (mg/dL) & $176.52 \pm 63.96$ & $74-324$ & $175.78 \pm 53.12$ & $106-384$ & $293.33 \pm 101.11$ & $231-410$ & $=0.006$ \\
\hline Triglycerides (mg/dL) & $85.39 \pm 54.04$ & $21-236$ & $125.16 \pm 113.33$ & $28-657$ & $182 \pm 77.07$ & $|37-27|$ & $=0.170$ \\
\hline Spot urine calcium/creatinine & $0.05 \pm 0.04$ & $0.01-0.16$ & $0.10 \pm 0.11$ & $0.01-0.54$ & $0.30 \pm 0.29$ & $0.02-0.60$ & $=0.002$ \\
\hline Spot urine protein/creatinine & $1.15 \pm 3.38$ & $0.05-15.11$ & $\mid .54 \pm 4.31$ & $0.06-17.57$ & $9.82 \pm 16.76$ & $0-29.18$ & $=0.026$ \\
\hline
\end{tabular}

Table 3. Total steroid doses of patient groups

\begin{tabular}{|c|c|c|c|c|c|c|}
\hline \multirow[b]{2}{*}{ Bone parameters } & \multicolumn{2}{|c|}{ Group I } & \multicolumn{2}{|c|}{ Group 2} & \multicolumn{2}{|c|}{ Group 3} \\
\hline & Mean $\pm S D$ & Min.-Max. & Mean $\pm S D$ & Min.-Max. & Mean $\pm S D$ & Min.-Max. \\
\hline Total steroid dose (mg) & $7247 \pm 4835.67$ & $689-15245$ & $7825.58 \pm 6029.06$ & $1385-29545$ & $4367.67 \pm 2729.71$ & $1320-6588$ \\
\hline Total steroid dose $(\mathrm{mg} / \mathrm{kg})$ & $234.70 \pm 114.22$ & $57-508$ & $306.67 \pm 205.84$ & $58-921$ & $209.33 \pm 135.97$ & $62-330$ \\
\hline
\end{tabular}


Table 4. The bone densitometry results of the patients $(n=43)$

\begin{tabular}{|c|c|c|c|c|c|c|c|}
\hline \multirow[t]{2}{*}{ Gender } & \multicolumn{2}{|c|}{ Normal } & \multicolumn{2}{|c|}{ Osteopenia } & \multicolumn{2}{|c|}{ Osteoporosis } & \multirow[t]{2}{*}{$\mathbf{p}$} \\
\hline & $\mathbf{n}$ & $\%$ & $\mathbf{n}$ & $\%$ & $\mathbf{n}$ & $\%$ & \\
\hline Group I $(n=17 / 20)$ & 14 & 82.4 & 3 & 17.6 & 0 & 0 & $=0.79$ \\
\hline Group $2(n=24 / 33)$ & 13 & 54.2 & 10 & 41.7 & 1 & 4.2 & $=0.79$ \\
\hline Group $3(n=2 / 3)$ & 2 & 100 & 0 & 0 & 0 & 0 & $=0.79$ \\
\hline
\end{tabular}

Table 5. The distribution bone density measurement of the patient groups according to gender

\begin{tabular}{|c|c|c|c|c|c|c|c|}
\hline \multirow[t]{2}{*}{ Gender } & \multicolumn{2}{|c|}{ Normal } & \multicolumn{2}{|c|}{ Osteopenia } & \multicolumn{2}{|c|}{ Osteoporosis } & \multirow[t]{2}{*}{$\mathbf{p}$} \\
\hline & $n$ & $\%$ & $\mathbf{n}$ & $\%$ & $\mathbf{n}$ & $\%$ & \\
\hline Female & 8 & 57.1 & 6 & 42.9 & 0 & 0 & $=0.386$ \\
\hline Male & 21 & 72.4 & 7 & 24.1 & I & 3.4 & $=0.340$ \\
\hline
\end{tabular}

Table 6. Ophthalmic symptoms of the patients $(n=40)$

\begin{tabular}{lccccccc}
\hline & \multicolumn{2}{c}{$\begin{array}{c}\text { With } \\
\text { cataract }\end{array}$} & & \multicolumn{2}{c}{$\begin{array}{c}\text { Without } \\
\text { cataract }\end{array}$} & p \\
\cline { 2 - 3 } & n & $\%$ & & n & $\%$ & \\
\hline Group I $(n=15 / 20)$ & I & 6.7 & & 14 & 93.3 & $=0.552$ \\
Group 2 $(n=22 / 33)$ & - & - & & 22 & 100 & $=0.458$ \\
Group 3 $(n=3 / 3)$ & - & - & 3 & 100 & $=0.557$ \\
\hline
\end{tabular}

3 groups and compared with regard to side effects using the chi-square test. There was no statistically significant difference $(p=0.715)$. The cataract rate can be seen in Table 6 .

\section{DISCUSSION}

The importance of corticosteroid treatment in childhood NS is indisputable; however, glucocorticoid drugs can have adverse effects on bone metabolism and the eyes. Longterm use can lead to osteoporosis and more frequent instances of cataract syndrome. ${ }^{[13-16]}$ When the appropriate precautions are taken, the development of osteoporosis and cataract can be prevented.

In to the literature on the effects of glucocorticoids on bone metabolism, there is a dose table that classifies prednisolone doses as follows: low dose ( $<2.5 \mathrm{mg} / \mathrm{day})$, medium dose $(2.5-7.5 \mathrm{mg} /$ day) and high dose (>7.5 mg/day). It has been reported that $5 \mathrm{mg} /$ day prednisolone use (supraphysiological doses) for 3 months is sufficient to inhibit bone formation indicators. ${ }^{[7]}$ In our study, we did not detect a statistically significant relationship between steroid dose and bone density, despite the fact that the patients received supraphysiological doses of steroids.
Studies have stated that biochemical changes return to normal once NS is in remission. ${ }^{[17,18]}$ In this study, 53 of the patients were in remission. Our findings supported these studies; the serum calcium, phosphorus, magnesium, alkaline phosphatase, parathyroid hormone, vitamin D, and osteocalcin levels of these patients were in the normal range.

In addition to studying the daily dose of steroids, there are also studies that have been performed examining the effects of peak doses, current doses, and cumulative doses. Cumulative dose has been shown to have the maximum effect on bone. Use of steroids every other day did not demonstrate any protective effects. ${ }^{[7,19,20]}$ However, other studies have reported that cumulative steroid dose does not affect bone density in steroid-sensitive NS patients. ${ }^{[21,22]}$ Similarly, we did not find a statistically significant difference between the cumulative dose of steroid and bone density.

Systemic steroids increase calcium excretion by increasing bone resorption. ${ }^{[23]}$ Our study results support this finding and indicated that the spot urine calcium/creatinine rate of Group 3 patients who were in the active stage and who were receiving treatment dose of steroid were significantly higher.

Osteocalcin, which is a non-collagen protein located in the bone matrix, is a good indicator of bone formation. It is also a good indicator of the inhibitory effect of corticosteroids. It has been shown that the intake of I oral dose of prednisolone $(2.5 \mathrm{mg})$ affects the serum osteocalcin level in adults immediately. ${ }^{[23]}$ In our study, there was no significant difference in the osteocalcin level of the patients. However, it is noteworthy that the majority of our patients were in the remission stage and that the mean osteocalcin level of Group 3 patients was lower than that of the others. 
In the literature, it has been demonstrated that high-dose steroid treatment leads to a decrease in bone structure, which causes the levels of alkaline phosphatase and osteocalcin. The 25-hydroxyvitamin D vitamin level of patients increased after treatment; however, remained lower than that of the control group. ${ }^{[17]}$ We did not encounter a statistically significant difference between the patient groups in terms of osteocalcin, alkaline phosphatase, or 25-hydroxyvitamin D vitamin level. There are 2 possible reasons for this result. First, the cumulative dose of steroids used in our study is lower than that used in other studies. According to the study performed by Biyikli et al., ${ }^{[17]}$ the cumulative steroid dose in patients with frequent relapses was $105,000 \mathrm{mg} / \mathrm{m} 2$ and the cumulative steroid dose in the patients with rare relapses was $28,125 \mathrm{mg} / \mathrm{m}^{2}$. In our study, the cumulative dose was $7193 \mathrm{mg} / \mathrm{m}^{2}$. Second, the majority of our patients were in the remission stage.

Secondary hyperparathyroidism is rare in nephrotic children. ${ }^{[17]}$ There was no case with secondary hyperparathyroidism among our patients. Hypomagnesemia can prevent parathormone secretion and the effects of parathormone on bone. However, we did not observe this in the present study.

Corticosteroids can lead to ophthalmic complications, such as increased intraocular pressure and posterior subcapsular cataract. Subcapsular cataract has been reported in nephrotic children treated with corticosteroids. The incidence varies between $14 \%$ and $51 \%$. In a study performed by Hayasaka et al., ${ }^{[2]} 54$ patients with NS who were treated with steroids for a long time were analyzed. According to their results, subcapsular cataract was detected in 15 patients. The wide range of cataract incidence due to steroid treatment reported may be associated with different timing, doses, and different clinical groups. ${ }^{[25]}$ Unlike the literature, the cataract rate was $2.5 \%$ in our study.

Though the mechanism of cataract occurrence due to the steroid use has not yet been explained entirely, steroid exposure creates a higher risk in young children. ${ }^{[26,27]}$ In our study, there was only I patient with a cataract, who was aged 12 years. The total steroid dose used in the treatment of this patient was $11,907 \mathrm{mg}(265 \mathrm{mg} / \mathrm{kg})$ and the diagnosis age was 1.83 years.

Biochemical alterations, such as a reduction of serum calcium, an increase in urinary calcium excretion, and a decrease in serum osteocalcin level can occur in patients with NS in the active disease stage due to steroid treatment. These changes return to normal in the remission stage. Nonetheless, pediatricians should be very careful while following up with children who use steroids at a young age due to the possibility of cataract development.
Ethics Committee Approval

Ethics Committee of Meram Medical Faculty, no: I I0.

Informed Consent

The study design was retrospective observational study.

Peer-review

Internally peer-reviewed.

Authorship Contributions

Concept: S.G.Y., B.A.; Design: B.A.; Data collection \&/or processing: S.G.Y.; Analysis and/or interpretation: S.G.Y., B.A.; Literature search: S.G.Y.; Writing: S.G.Y.; Critical review: S.G.Y., B.A.

Conflict of Interest

None declared.

\section{REFERENCES}

1. Safaei AA, Maleknejad S. Clinical and laboratory findings and therapeutic responses in children with nephrotic syndrome. Indian J Nephrol 2010;20:68-71. [CrossRef]

2. Holmberg C, Tryggvason K, Kestila MK, Jalanko HJ. Glomerular disease. In: Avner E, editor. Pediatric Nephrology. New York: Lippincott Williams and Wilkins; 2004. p. 501-664.

3. Eddy AA, Symons JM. Nephrotic syndrome in childhood. Lancet 2003;362:629-39. [CrossRef]

4. Niaudet P. Etiology, clinical manifestations, and diagnosis of nephrotic syndrome in children. Available at: http://www.uptodate.com/ contents/etiology-clinical-manifestations-and-diagnosis-of-nephrotic-syndrome-in-children. Accessed Sep 5, 2017.

5. Hodson EM, Alexander SI. Evaluation and management of steroidsensitive nephrotic syndrome. Curr Opin Pediatr 2008;20:145-50.

6. Abeyagunawardena AS, Dillon MJ, Rees L, van't Hoff W, Trompeter RS. The use of steroid-sparing agents in steroid-sensitive nephrotic syndrome. Pediatr Nephrol 2003;18:919-24. [CrossRef]

7. Gökkaya NKO, Kutsal YG. İlaca bağl1 osteoporoz. Türk Osteoporoz Dergisi 2011;17:30-6.

8. Adler RA, Curtis JR, Saag K, Weinstein RS. Glucocorticoid-induced osteoporosis. In: Marcus R, Feldman D, Nelson DA, Rosen CJ, editors. Osteoporosis. 3rd ed. San Diego, CA: Elsevier-Academic Press; 2008. p. 1135-66. [CrossRef]

9. Hiz Ö, Karaaslan G, Yazmalar L, Tekeoğlu İ. Uzun Dönem Glukokortikoid Kullanımına Bağlı Gelişen Manifest Osteoporoz ve Sağ Femur Başı Avasküler Nekroz Birlikteliği: Olgu Sunumu. Van Tip Dergisi 2008;15:90-4.

10. Saag KG, Furst DE. Major side effects of systemic glucocorticoids. Available at: http://www.uptodate.com/contents/major-side-effectsof-systemic-glucocorticoids. Accessed Sep 5, 2017.

11. De Nijs E, Brabant P, De Laey JJ. The adverse effects of corticosteroids in central serous chorioretinopathy. Bull Soc Belge Ophtalmol 2003:35-41.

12. Campos LM, Liphaus BL, Silva CA, Pereira RM. Osteoporosis in childhood and adolescence. J Pediatr (Rio J) 2003;79:481-8.

13. Niaudet P. Complications of nephrotic syndrome in children. Available at: http://www.uptodate.com/contents/complications-of-nephrotic-syndrome-in-children. Accessed Sep 5, 2017. 
14. Pranić-Kragić A, Radić M, Martinović-Kaliterna D, Radić J. Glucocorticoid induced osteoporosis. Acta Clin Croat 2011;50:563-6.

15. Tanrıverdi Yüksel D, Ertan Ü, Baş AY, Yüksek M. . Çocukluk çağı hastalıklarında oral prednizolon tedavisi ile oluşan yan etkiler. Fiziksel Tip 2001;4:91-7.

16. Hachet E. Cataracts. Bull Soc Ophtalmol Fr 1985:87-107.

17. Biyikli NK, Emre S, Sirin A, Bilge I. Biochemical bone markers in nephrotic children. Pediatr Nephrol 2004;19:869-73. [CrossRef]

18. Huang JP, Bai KM, Wang BL. Vitamin D and calcium metabolism in children with nephrotic syndrome of normal renal function. Chin Med J (Engl) 1992;105:828-32.

19. Lettgen B, Jeken C, Reiners C. Influence of steroid medication on bone mineral density in children with nephrotic syndrome. Pediatr Nephrol 1994;8:667-70. [CrossRef]

20. Gulati S, Sharma RK, Gulati K, Singh U, Srivastava A. Longitudinal follow-up of bone mineral density in children with nephrotic syndrome and the role of calcium and vitamin D supplements. Nephrol Dial Transplant 2005;20:1598-603. [CrossRef]

21. Mishra OP, Meena SK, Singh SK, Prasad R, Mishra RN. Bone min- eral density in children with steroid-sensitive nephrotic syndrome. Indian J Pediatr 2009;76:1237-9. [CrossRef]

22. Esbjörner E, Arvidsson B, Jones IL, Palmér M. Bone mineral content and collagen metabolites in children receiving steroid treatment for nephrotic syndrome. Acta Paediatr 2001;90:1127-30. [CrossRef]

23. Saag KG. Glucocorticoid-induced osteoporosis. Endocrinol Metab Clin North Am 2003;32:135-57. [CrossRef]

24. Hayasaka Y, Hayasaka S, Matsukura H. Ocular findings in Japanese children with nephrotic syndrome receiving prolonged corticosteroid therapy. Ophthalmologica 2006;220:181-5. [CrossRef]

25. Afzal K, Bagga A, Menon S, Hari P, Jordan SC. Treatment with mycophenolate mofetil and prednisolone for steroid-dependent nephrotic syndrome. Pediatr Nephrol 2007;22:2059-65. [CrossRef]

26. Westhoff TH, Schmidt S, Zidek W, Beige J, van der Giet M. Tacrolimus in steroid-resistant and steroid-dependent nephrotic syndrome. Clin Nephrol 2006;65:393-400. [CrossRef]

27. Hofstra JM, Deegens JK, Wetzels JF. Rituximab: effective treatment for severe steroid-dependent minimal change nephrotic syndrome? Nephrol Dial Transplant 2007;22:2100-2. [CrossRef]

\section{Nefrotik Sendromlu Çocuklarda Steroid Tedavisinin Kemik ve Göz Üzerine Olan Etkileri}

Amaç: Bu çalışmada, uzun süreli steroid kullanımının göz ve kemik üzerine olan komplikasyonlarının erken dönemde tanı konularak gerekli tedbirlerin alınması amaçlandı.

Gereç ve Yöntem: Bu çalışma, Necmettin Erbakan Üniversitesi'nde Haziran 2006-Mayıs 20II tarihleri arasında Minimal Lezyon Hastalı̆ı nedeniyle steroid tedavisi alan nefrotik sendromlu hastalarda geriye dönük olarak yapıldı.

Bulgular: Çalışmaya toplam 56 hasta alındı. Hastaların ortalama tanı yaşı $4.2 \pm 2.3$ idi. Hastalar steroid kullanım sürelerine göre üç grup halinde incelendi. Grup I remisyonda olup son bir yıl içinde steroid tedavisi almayanlar, grup 2 remisyonda olup son bir yıl içinde steroid tedavisi alanlar, grup 3 aktif nefrotik fazda olup halen steroid tedavisi alanlar olarak tanımlandı. Üç grup biyokimyasal parametreler (serum üre, kreatin, kalsiyum, fosfor, magnezyum, alkalenfosfataz, parathormon, osteokalsin, D vitamini, trigliserit) açısından karşılaştırıldı, anlamlı fark bulunmadı. Grup 3'te spot idrar kalsiyum/kreatinin ve protein/kreatinin oranı grup I ve 2'den daha yüksek saptandı. Üç grup göz üzerine olan yan etkiler açısından karşılaştırıldı, istatistiksel olarak anlamlı fark bulunmadı ( $p=0.715$ ).

Sonuç: Pediatristler küçük yaşta steroid kullanan hastaların izleminde katarakt oluşum riski ve kemik metabolizması üzerine etkileri açısından dikkatli olmalıdır.

Anahtar Sözcükler: Göz komplikasyonları; kemik mineral yoğunluğu; kortikosteroid; nefrotik sendrom. 